\title{
The Renegotiation Act A Study in Government Litigation Tactics
}

\author{
Walker Lowry*
}

In each of these cases the District Court has held that the Act was constitutional and that, by failure to petition the Tax Court for their redetermination, the existing orders have become final, as claimed by the Government. Each Circuit Court of Appeals has afirmed, unanimously, the judgment appealed to it. We agree with the courts below. ${ }^{1}$

Hus Mr. Justice Burton closed four years of litigation. The valid-
ity of the Renegotiation Act had been under attack in several hundred cases. The stake was large. Re-examination of war contracts aggregating nearly $\$ 200,000,000,000$ had returned more than $\$ 3,000,000,000$ of excessive war profits to the United States. ${ }^{2}$ The theory of renegotiation, divorced from the complexities of the statute, was simple enough. Congress correctly concluded that profits on government war business are likely to be exorbitant and that an excess profits tax standing alone is too rigid to control profiteering either efficiently or fairly. Renegotiation therefore abandoned a formula definition of excessive profits appropriate to a revenue act in favor of an exercise of administrative judgment appropriate to a regulatory statute. The Act required each person doing war business with the Government, directly or indirectly, to refund to the United States the amount by which his profits in the judgment of government officials were excessive. Those who were dissatisfied with the figure fixed by

* Member of the California Bar. Attorney, U. S. Department of Justice 1944-46, in immediate charge of litigation involving the validity of the Renegotiation Act.

1 Lichter v. United States (1948) 334 U. S. 742, 746.

2 See the Government brief in Licliter v. United States, Supreme Court, Octoher term, 1947, Nos. 105, 74, and 95, p. 52. To what extent the United States would have been required to refund this $\$ 3,000,000,000$ if the Supreme Court had voted for invalidity no one surely knows. More than $90 \%$ of the refunds were made pursuant to closing agreements. (Renegotiation Act, Sec. 403 (c)(4), 56 STAT. 245 (1942), as amended 56 Stax. 982 (1942), 58 Stat. 78 (1944), 50 U. S. C. ApP. 81191 (1946)). The circuit courts have said that the determination that a tax statute is unconstitutional does not affect the validity of a closing agreement executed prior to the decision. Wolverine Petroleum Corp. v. Commissioner (C. C. A. 8th 1935) 75 F. (2d) 593 and cases cited therein. Here, however, the entire act was challenged. If the statute in its entirety had been unconstitutional it might have been argued that Government officials were therefore without authority to execute the closing agreements and bence that the agreements were of no effect. 
the administrative officers were free to obtain from the Tax Court a new and final determination of the amount to be refunded.

The constitutional issues most fervently debated in connection with the statute were (a) that the Act unlawfully delegated legislative authority, (b) that the recapture of excessive profits constituted a taking of property for public use without payment of compensation, ${ }^{4}$ (c) that the Act was invalid for retroactivity, ${ }^{5}$ and (d) that there were fatal failures of procedural due process. ${ }^{6} \mathrm{Mr}$. Justice

3 The Act, prior to amendments effective February 25, 1944, directed a refund of "excessive profits" without defining the term or enumerating the factors to be considered. Upon the authority of Carter v. Carter Coal Co., (1936) 298 U.S. 338, Schechter Corp. v. United States (1935) 295 U.S. 495, Panama Refining Co. v. Ryan (1935) 293 U. S. 388, Small Co. v. American Sugar Refining Co. (1925) 267 U. S. 233, Weeds v. United States (1921) 255 U. S. 109, and United States v. Cohen Grocery Co. (1921) 255 U.S. 81, it was argued that this constituted an unlawful delegation of legislative power to administrative officials. The Government in reply relied principally upon Bowles v. Willingham (1944) 321 U.S. 503, Yakus v. United States (1944) 321 U.S. 414, Hirabayashi v. United States (1943) 320 U.S. 81, Opp Cotton Mills v. Administrator (1941) 312 U.S. 126, Mutual Film Corp. v. Ohio Industrial Comm. (1915) 236 U.S. 230, Union Bridge Co. v. United States (1907) 204 U.S. 364, and Buttfield v. Stranahan (1904) 192 U.S. 470.

${ }^{4}$ The plaintiffs cited Louisville Joint Stock Land Bank v. Radford (1935) 295 U.S. 555 and Lynch v. United States (1934) 292 U.S. 571 . The Government relied upon Dayton-Goose Creek Ry. v. United States (1924) 263 U.S. 456.

5 The Act, effective April 28, 1942, applied to contracts in existence on that date. Moreover, the amendments of October 21,1942 , and July 1, 1943, each increasing the area of operation of the statute, were made retroactive to the date of the original enactnuent. Upon the authority of Perry v. United States (1935) 294 U.S. 330, Lynch v. United States, supra note 4, Coohidge v. Long (1931) 282 U.S. 582, Untermyer v. Anderson (1928) 276 U.S. 440, Blodgett v. Holden (1927) 275 U.S. 142, and Nichols v. Coolidge (1927) 274 U.S. 531, it was contended that the attempt at retroactivity was invalid. The Government cited Bowles v. Willingham supra note 3 , Welch v. Henry (1938) 305 U.S. 134, United States v. Hudson (1937) 299 U.S. 498, Norman v. Baltimore \& Ohio R. Co. (1935) 294 U. S. 240, and Home Bldg. \& Loan Assn. v. Blaisdell (1934) 290 U.S. 398.

${ }^{6}$ The Act as it became law April 28, 1942, contained no significant procedural provisions. By the Revenue Act of 1943 the statute was amended to allow a de novo redetermination of the amount of excessive profits by the Tax Court; but the Tax Court decision was by the statute made final and beyond review. This, it was argued, was a failure to comply with the requirenients of procedural due process. The authorities cited by the plaintiffs included Morgan v. United States (1938) 304 U.S. 1, Railroad Commission of California v. Pacific Gas \& Electric Co. (1938) 302 U.S. 388, Ohio Bell Tel. Co. v. Public Utilities Commission (1937) 301 U.S. 292, United States v. Baltimore \& Ohio R. Co. (1935) 293 U.S. 454, Southern Ry. Co. v. Virginia (1933) 290 U.S. 190, Monongahela Navigation Co. v. United States (1893) 148 U.S. 312, and Chicago, Milwaukee \& St. Paul Ry. Co. v. Minnesota (1890) 134 U.S. 418. The Government relied upon Opp Cotton Mills, Inc. v. Administrator, supra note 3, Utley v. St. Petersburg (1934) 292 U.S. 106, Phillips v. Commissioner (1931) 283 U.S. 589, Milheim v. Moffat Tunnel Dist. (1923) 262 U.S. 710, Farncomb v. Denver (1920) 252 U.S. 7, etc. 
Burton's opinion removes the possibility of significant debate of these issues. All are resolved in favor of the statute. The opinion does not reveal, of course, the tactical problems which came to the Government for resolution in the course of the litigation.

Of these the most important, and certainly the most difficult, was to see to it that the litigation, pending a Supreme Court decision, did not interfere with the administrative program. The Government experience with the Public Utility Holding Company Act of 1935 had not been forgotten. The rush of litigants to attack that statute had persuaded the SEC and the Attorney General to accept, for most purposes, a postponement of the act pending a determination of validity. ${ }^{7}$ A comparable delay of months and perhaps years in the enforcement of the Renegotiation Act could hardly have been tolerated. For one thing renegotiation, designed to control profiteering, was intimately related to war morale. For another, it would have been thoroughly unfair to government contractors, under continuous pressure to expand their plants and their commitments, to leave for post-war decision an undefined liability to refund profits to the Government. This was particularly true since, with one or two notable exceptions, the more responsible business interests recognized the public relations value of renegotiation and were anxious to reach agreement with the Government as to permissible profits. And finally it was not entirely without significance that net recoveries under the statute were accumulating at the rate of several hundred million dollars a year. Taken together these considerations left the Government no choice. The program had to go forward in spite of the litigation.

The problem, it was plain to be seen, was only one more illustration of the difficulty of devising a satisfactory working relationship for courts and administrative agencies. No procedural question in public law has been more persistent or perplexing. The trouble, essentially, is that the conflicting considerations are almost equally legitimate. It is certainly true that the Government must get its business done; that it must for that purpose have freedom and flexibility, the capacity and the authority to adjust its means to its ends. It is equally certain, however, that the judicial system, the accepted repository of the due process tradition, generally displays a capacity for fair treatment and fair decision which executive administrators frequently fail to equal. The proponents of government quite properly demand freedom for government to accomplish its purposes; the proponents of fair deal-

‘ Landis v. North American Co. (1936) 299 U.S. 248. 
ing call with equal justification for judicial supervision of administrative action to protect the fundamental freedoms for which government exists.

Whether the solution lies in the current compromise called the Federal Administrative Procedure Act or elsewhere is yet to be seen. But one thing is evident: nothing will more surely destroy all hope for administrative responsibility, for an administrative tradition equal in dignity to the judicial tradition, than to permit the courts systematically to rob adninistrative tribunals of their power and authority. To insist that administration reach its conclusions fairly by methods beyond reproach is one thing; to remove every significant problem to the courts for decision is quite another. The former recognizes and emphasizes administrative authority, seeking only to provide administration with the best methods for fair dealing within the repertoire of the Anglo-American tradition. The latter, by placing upon the courts the burden of decision, overloads the judiciary with tasks for which it is ill-equipped and, more important, it inevitably fosters ill-considered, hasty and irresponsible action by administrative officers who know too well that in the end the court will have the final say. Men in government, like other men, become responsible by having responsibility placed upon them.

The one certain method for destroying all administrative authority and responsibility is the careless use of restraining orders and injunctions. The first impulse of any busy judge faced with an attack upon administrative action, or a challenge to the authority of the administrative tribunal, is to suspend enforcement measures until the questions at issue are finally decided. With one injunction issued, each succeeding injunction is obtained with less difficulty until as a practical matter they issue at request. The courts thus assume the full burden of the administrative program, the executive officer is completely robbed of all purpose and authority, and enforcement of the act reaches a confused and untimely end. The government lawyer, seeking to protect the administrative program, must therefore defeat if he can the first and each succeeding application for an injunction.

This problem of injunctive relief was particularly acute with renegotiation because of the extraordinary powers of self-help which the Act gave to the Government. For collecting amounts owing on renegotiation orders the statute provided three techniques. First, the Government was authorized to offset renegotiation debts against any payment which might be due from the United States to the renegotia- 
tion debtor. Second, the Government was provided with powers of administrative garnishment, the power to order Government contractors indebted to persons in default on renegotiation orders to pay the United States rather than their creditors. Third, affirmative suits in the federal courts were authorized when all else failed. The first two methods of collection, by offset and administrative garnishment, were by all odds the most popular with government fiscal officers. Immediately upon completion of administrative renegotiation, socalled withholding orders were issued to collect what was said to be owing. The consequence to the contractor was frequently overwhelming. His accounts receivable, upon which his payrolls depended, were suddenly throttled. Not unnaturally he hurried to his lawyers and not unnaturally the lawyers hurried to court demanding that the accounts be released pending a determination of the issues between the parties.

Through the early period of the renegotiation debate the Government was more than occupied in meeting these demands for injunctive relief. The Department of Justice was, of course, long since expert in suits against the United States or its officers and all the standard defenses were put to work. It was argued, first, that an action to restrain the Secretary of War or the Secretary of the Navy from enforcing the statute constituted a suit against the United States to which there had been no consent and which was, therefore, beyond the jurisdiction of the court. ${ }^{8}$ This argument was vigorously advanced in Lincoln Electric Co. v. Knox, the first case challenging the statute. ${ }^{10}$ It met, however, with no success. A three-judge court of the District of Columbia rejected the Government's position. When, however, a case arose in which the renegotiation debt could be fully collected by offsetting amounts otherwise owing from the United States to the plaintiff, the Government argument prevailed.11 It was held that such a suit, designed as a practical matter to obtain funds from the Treasury, was inevitably a suit against the United States to which there had been no consent. In the great majority of cases, however, as in the Lincoln case, offsetting alone would not collect the renegotiation debt. The Government was forced, therefore, to find other arguments to defeat the injunctions.

${ }^{8}$ See the cases collected in Aircraft \& Diesel Corp. v. Hirsch (1947) 331 U.S. 752, Macauley v. Waterman S.S. Corp. (1946) 327 U.S. 540, and Mine Safety Appliances Co. v. Forrestal (1945) 326 U.S. 371.

9 (D. C. 1944) 56 Fed. Supp. 308.

10 The Lincoin case was filed November 3, 1943.

11 Mine Safety Appliances Co. v. Forrestal, supro note 8, affirming (D. C. 1945) 59 Fed. Supp. 733. 
The Government's second contention was that the plaintiffs had an adequate remedy in the law courts. The statute itself said nothing about forums for litigation except to provide for a redetermination of the amount of excessive profits by the Tax Court. ${ }^{12}$ It turned out, however, that the enforcement procedures described in the Act provided indirectly the litigation forums which Congress had failed to specify. If, for example, the Government's collection method was to offset payments otherwise due on a contract, the contractor, it seemed plain, could sue in the Court of Claims on his agreement and force the Government to justify its position by setting up the renegotiation order. The Court of Claims could then test the validity of the statute upon the authority of which the order was issued. In similar fashion when the collection technique was administrative garnishment, i.e., by directing third persons to pay the United States sums otherwise owing to the renegotiation debtor, a suit was available on the original debt. In that suit the "garnishee" could have no defense except the government order issued under authority of the Renegotiation Act. Again, the validity of the statute was before the court. ${ }^{13}$ Finally, the third method of collection, an affirmative suit on behalf of the United States against the renegotiation debtor, inevitably brought the statute into question. Thus, on the Government argument, there was for every contractor a law forum open for litigation. ${ }^{14}$

12 Renegotiation Act, Section $403(\mathrm{e})(1)$. The Act contained the further provision that this determination should "not be reviewed or redetermined by any court or agency." In spite of the language it was scarcely conceivable that Congress could have intended to make Tax Court decisions final on the question of constitutionality. Nor was the Government disposed to argue for this proposition even if there had been hope of sustaining it. The Government believed as firmly as the contractors that the Supreme Court should decide the constitutional issues. This belief plus the ambition to avoid injunctions unade the Government twice eager to discover methods of litigation on the law side.

13 The first renegotiation case to reach a Circuit Court, Spaulding v. Douglas Aircraft Co. (C. C. A. 9th 1946) 154 F. (2d) 419 , was a case of this sort. The Government directed Douglas Aircraft Company to withhold sums otherwise owing to its sub-contractor, Manlove \& Spauiding, a renegotiation debtor. Manlove \& Spaulding sued Douglas alleging that Douglas was withholding contract payments on the authority of a renegotiation order and that the order and statute were invalid. Since the constitutionality of an act of Congress was thus in issue, District Judge Ben Harrison certified that fact to the Attorney General who appeared to defend the statute.

14 In most of the equity cases affidavits were filed by the government enforcement offeers describing the collection methods which were contemplated. The courts at first looked upon these affidavits with little entliusiasm. What, they asked, was to prevent the fiscal officer from changing his mind? Eventually, however, as the affidavits were scrupulously honored they were fully accepted by the judges, particularly when they were supported by an open court commitment from government counsel. 
The logic of the Government argument was impeccable as far as it went. But the scheme had one flaw often fatal. Enforcement of a renegotiation order might involve fifteen or twenty withholding orders to government "garnishees". Must we, the plaintiffs asked, file fifteen or twenty lawsuits to protect our rights? What have government counsel to say about that venerable ground of equity jurisdiction to prevent multiplicity of actions? Mr. Justice Black in Macauley v. Waterman S. S. Corp..$^{15}$ seemed unimpressed with this contention, but it was difficult to believe that it had no validity, and the Government never succeeded in developing a fully persuasive answer to the multiplicity argument. Occasionally the enforcement officials could be persuaded to reduce the number of withholding orders to two or three, but usually they insisted on issuing the orders they felt appropriate, leaving to counsel the problem of maintaining the Government's position on injunctive relief. Not infrequently that was beyond counsel's ingenuity. ${ }^{16}$

Under these circumstances the Government was prone to suggest a stipulation, the form of which had been devised early in the renegotiation litigation. Certain of the early plaintiffs had no genuine ambition to press their suits. Their true objective was an arrangement protecting their rights pending a final determination of constitutionality. The problem was to secure the Government during the litigation period. A form of stipulation was evolved for this purpose which eventually became standardized. It called for a deposit of government bonds in an amount adequate to secure full payment of the renegotiation order with interest, and it went on to provide that if the injunction suit was dismissed or decided, for any reason, in favor of the Government recourse could be had, if necessary, to the securities

\footnotetext{
15 Supra note 8.

16 The situation from the government point of view was sometimes saved by an appeal to the doctrine of exhaustion of administrative remedies. Occasionally the private litigants went to court before the administrative procedures were complete. For instance in Macauley $v$. Walerman $S$. $S$. Corp., the plaintiff filed suit when the administrative proceedings were only begun, claiming exemption from renegotiation and asking that further proceedings be enjoined. The customary prayer for declaratory relief appeared in the complaint. The district court on the authority of Myers v. Bethlehem Shipbuilding Corp. (1938) 303 U.S. 41, and comparable cases, dismissed the action. The Court of Appeals for the District of Columbia reversed (151 F. (2d) 292) insisting that the demand for a declaratory judgment was well taken. The Court of Appeals was unwilling to enjoin further administrative proceedings but suggested an informal truce between the parties pending the outcome of the litigation. The Supreme Court reinstated the decision of the district court, reaffirming the traditional doctrine requiring exhaustion of administrative remedies.
} 
on deposit. ${ }^{17}$ The stipulation contained no final commitment from either side as to conduct of the suit. The plaintiffs, however, were usually willing to let other persons carry the litigating burden, and the Government, adrift in a flood of litigation in any event, was not eager to press forward with suits where its position was plainly secure. Almost without exception the stipulations put at rest the cases in which they were executed. ${ }^{18}$

By diligent attention to the jurisdictional arguments and resort to stipulations where all else failed, the Government was largely successful in avoiding injunctions against the administrative process. ${ }^{19}$ At best, however, these were makeshift methods, clumsy substitutes for a direct congressional mandate.

For the fundamental question, the question as to the extent to which enforcement of novel legislation shall be postponed pending a judicial determination of its validity, is a question of policy which ought to reside not with the courts but with Congress. In the Emergency Price Control Act, Congress solved that question by withdrawing all judicial power to restrain enforcement of price orders. This device obviously defeats not only the abuse but the legitimate use of the power of the courts to protect the citizen. ${ }^{20} \mathrm{~A}$ step so radical can

17 Deposits under these stipulations totaled millions of dollars and there was some difficulty in finding a willing stakeholder. The Federal Reserve Banks eventually assumed this duty.

18 The stipulations were a technique of litigation and they were executed only in cases where the propriety of an injunction was lionestly in doubt. If it was clear that no injunction would issue no stipulation was signed. The Attorney General has power to conduct litigation; he has no power to establish general administrative policy.

19 On one or two occasions temporary restraining orders were authorized but the difficulties of framing a temporary order which runs against the United States and its officers are not unsubstantial. In inost instances, after a series of unproductive conferences between court and counsel, a stipulation was substituted for a formal order.

20 Whatever the consequences to administration, it seems clear that the courts inust retain their basic power to enjoin illegal action taken in the name of the Government which honestly threatens irreparable injury to the citizen. It is equally plain, however, that the reckless use of injunctions can result in complete frustration of the public will. It is attractive but completely erroneous to assume that the call upon the courts is always from the deserving citizen seeking protection against the tyranny of bureaucracy. Actually the deserving citizen is not conspicuous among those who contest the validity of legislation. The demand for judicial relief all too frequently comes from the opponents of legislation who seek to win through confusion and failures in administration the battle lost in Congress or, at the very least, to postpone the evil day when the mandate of the statute inust be observed. The injunctive powers of the courts are admirably adapted to create this confusion and delay. No public program can operate effectively if at the request of every opponent the government machinery inust stop while through many months the courts struggle to arrive at the final determination of every debatable issue. 
be justified only in extreme cases. In most instances a more appropriate policy is to employ legislative techmiques designed to eliminate any genuine irreparable injury from enforcement of a statute ultimately held invalid. ${ }^{21}$ It seems clear, for example, that the Renegotiation Act should have stated in unequivocal terms that the Government would refund with interest any amount unlawfully collected under a renegotiation order. It should then have gone on to withdraw all judicial power to enjoin enforcement of the statute, except upon plain proof that a refund would not in fact be an adequate remedy for the contractor. ${ }^{22}$ In a single sentence Congress could have accomplished all that the courts achieved after months of litigation.

With the administrative machinery reasonably well protected from disruption by injunction, the Government set about considering its second tactical problem, the preparation and presentation of its argument on the constitutional questions. The auspices were favorable. The courts, in general, were anxious to support the war program,

21 Although the amendments to the Renegotiation Act effected by the Revenue Act of 1943 provided for a redetermination of the amount of excessive profits by the Tax Court, the statute failed to provide in specific language for a refund of amounts erroneously collected by the Government. It did provide that an appeal to the Tax Court should not stay enforcement of renegotiation orders (Sec. 403 (e)(1)). From this the Government argued that the implication of an obligation to make the refund was inescapable and, therefore, that a contractor could safely pay the original determination without fear of ultimate loss. This position was supported by legislation appropriating several million dollars to make renegotiation refunds. (Pub. L. No. 40, 79th Cong. 1st Sess.) However, the courts were never fully persuaded that this refund machinery would be completely effective if the statute in its entirety was declared unconstitutional.

${ }^{22}$ This or an equivalent provision might well appear in every major statute. Each new and debatable act of Congress might well contain language specifically providing the extent to which, if at all, enforcement of the statute is to be suspended during an initial litigating period of two or three years. If the only impact of the law is a money demand, refund machinery with an interest payment would seem to be adequate protection for the citizen. This, of course, is familiar practice under the revenue laws. If, however, the new legislation is regulatory, the problem obviously becomes more comphicated. For one thing, it is ustrally difficult and often impossible to measure in monetary terms the damage sustained through enforcement of unconstitutional regulatory legislation. Even here, however, there should be a dellherate judgment of Congress on the enforcement question. Congress should weigh the public importance of immedlate enforcement against the harm to individual citizens if in the end the statute proves to be unlawful. Preliminary matters such as information requests, administrative hearings, valuation orders, etc., can no douht go forward without waiting for the constitutional litigation. More drastic orders should, perhaps, be effective only when the statute is proved to be valid. The important thing, however, is to obtain from Congress a dellberate decision as to what is intended and thereby free the public, the courts and the executive officers of the Government from a large part of the confusion which is normally attendant on the initiation of a new government program. 
and no one befriends a profiteer. The constitutional questions, however, were fairly in debate. Moreover, the Government in order to protect the administration of the Act was anxious to win not only in the Supreme Court but all along the line. The Government had good reason, therefore, to get its best foot forward.

An unmistakable clue to strategy was provided by the lawyers exposed to renegotiation. The first impression of the Act was almost always unfavorable. It was drastic, sketchy and bristling with constitutional problems. But further acquaintance inspired confidence. When the purpose of the statute became known, when the problems of procurement and pricing were explained, renegotiation appeared preeminently reasonable. Anyone could read the lesson. The job of the Government advocate was to inform the courts of the meaning, the purpose and the result of the statute. ${ }^{23}$

As in every constitutional campaign this objective was rendered more difficult by the procedural device American law employs to resolve constitutional questions. It is the dogma of the common law that each decision decides only the rights of the parties. From this it is held to follow that the court record must recite nothing except the facts of the particular case. The basic assumption is never exact truth and when applied to constitutional cases it is hardly more than nonsense. Almost always a single Supreme Court decision determines the fate of any piece of legislation and thus determines the rights of all persons, perhaps millions, within the legislative command. The fact that in the American system legislation for the entire nation survives or falls upon the examination of one instance of its operation has essential elements of absurdity. No Congressional committee, for example, would undertake to recommend repeal of a statute after consideration of its effect in a single case.

23 In essence the Government's position before the courts was and had to be that renegotiation was fair and reasonable. That position could be maintained only as long as renegotiation was in fact fair and reasonable. The policies established for administration of the Act were admirably adapted to sustain this conclusion. No serious effort was made to extend the statute into areas of doubtful applicability and a vast amount of peripheral debate was thereby avoided. Nor was any attempt made to wring from the public every last dollar of doubtful earnings. Profits which within reason could be said to be legitimate were in most instances beld to be legitimate. This does not suggest that the renegotiators were remiss in the discharge of their duties. Quite the contrary. Successful government depends upon the achievement of large and usually simple ohjectives. Neat logic and fine distinctions are rarely useful in the rough and tumble business of government. Better tools for that arena are a gift for perspective and a willingness to go forward along the main lines. These talents the renegotiation officials displayed in large measure. 
Actually, as everyone knows, the Court does what it can to broaden the basis of decision. Judicial notice in constitutional cases reaches all ordinary information, within or beyond the record, and the Court customarily seeks such light as may be found in the legislative history. Even so, the Court in most cases can rarely learn anything of importance about the impact of the statute on the nation. Yet it is precisely this information which is of most significance. Once a substantial amount of experience with a statute has accumulated the best evidence of its value is found neither in the Congressional record nor in the circumstances of a particular case. It is found in a determination of how public welfare has in fact been affected by the law. This is particularly true when the question for decision is essentially a question of fairness, or, to use lawyers' language, a question of substantive due process. The Anglo-American judicial system has, however, no accepted procedure for providing the courts with this information. A court in this country can and does determine whether on a given occasion a traffic regulation was violated. It has no real way to determine whether the operation of the regulation is in general sensible and fair.

The problem of presenting to the courts the economic facts justifying the position of Congress was particularly acute with the Renegotiation Act. The Act became effective within a month of the day Representative Case first proposed a profit limitation. The course of the legislation in Congress was such, moreover, that the legislative record was scanty at best and often more confusing than helpful..$^{\text {th }}$ Some special effort was plainly required to prevent the courts from undertaking to nullify the Act without in truth knowing anything about it.

24 On March 28, 1942 when the House was considering the Sixth Supplemental National Defense Appropriation Act, 1942, Representative Case of South Dakota offered an amendment which forbade the use of the appropriated funds to make payment to a contractor who failed to agree to refund his profits in excess of $6 \%$. The House immediately adopted the Case amendment and sent the Act to the Senate. Procurement officials were horrified. In their judgment nothing would more effectively frustrate the procurement programs than a rigid profit limitation of $6 \%$, particularly when the basic figure of which $6 \%$ was to be taken was not identified. A sub-committee of the Senate Committee on Appropriations saw the point but demanded that the representatives of the War and Navy Departments provide immediately a substitute method for controlling war profits. Renegotiation, which was already under way on a voluntary basis, was proposed. The Committee did not fully agree and the bill, as it went to the Senate floor contained no profit limitation. On the floor Senator McKellar obtained Senate approval of a somewhat different profit limitation provision. This provision was also unsatisfactory to the services and the Renegotiation Act in the form in which it became law was hastily worked out in conference between the two Houses. 
In its purpose to provide the courts with full information the Government was considerably assisted by the division of labor between the Tax Court and the district courts on renegotiation matters. Under the statute the Tax Court alone had power to consider the complicated fact issues surrounding a determination of the amount of excessive profits. The district courts, where the statute was most vigorously under attack, were therefore concerned exclusively with issues of law. Summary judgment thus became available as a method of litigation.

The Government took this opportunity to prepare and file elaborate affidavits of the Undersecretary of War and the Assistant Secretary of the Navy, describing in statements replete with dates, names and figures the size and nature of the war procurement program, the impossibility of accurate forward pricing on many war materials, the extent of profiteering and the deficiencies of the customary methods of control. To this extent the affidavits duplicated what might normally have been found in the legislative history. But the affidavits went further. They set out with precision the procedures which had been adopted under the Act and the results which had been accomplished. The purpose, of course, was to provide data on what, after all, is the most satisfactory test of substantive due process; i.e., public experience under the Act. ${ }^{25}$ These affidavits, printed in volume, were filed in all the early renegotiation cases. Generally speaking they were favorably received by the courts. ${ }^{28}$

25 In the Tax Court no procedure equivalent to summary judgment is available. As the constitutional issues arose in that court, procurement officials of the Army and Navy presented the same basic data by oral testimony.

203 See Mr. Justice Burton in Lichter v. United States (1948) 334 U.S. 742. There are obvious advantages and equally obvious objections to this method of supplementing the information otherwise available to the judges. Affidavits can be prepared at length and with care to reveal in detail the scope and complexity of a national problem. The courts thus have an opportunity to ground their decisions in reality and to acquire a perspective which reduces the chance that the idiosyncrasies of a particular case will decide the fate of the law. The affidavits (or equivalent testimony) can also reveal national experience under the law, information which under conventional methods of preparing the record is almost certain to be lacking.

On the other hand, even though no responsible government official is likely to swear to untruths or deliberately suppress adverse imformation, those in charge of a program can hardly be expected to emphasize its failures, and the record may to that extent be biased. Moreover, the only resource of the private litigant for meeting the government material is to compile a list of "horrible examples." The court may then find itself trying not one but many cases. In addition, if afidavits cannot be used, the time consumed by government officials in testifying in a host of cases might well be prohibitive of the practice.

For these and other reasons it is clear that the affidavit technique is by no means an ideal answer to the fundamental problem. There is, perhaps, no perfect solution for 
With the affidavits on hand to provide renegotiation information and with summary judgment selected as the litigation technique the Government then set about considering the problem of a test case. This question, in a sense, is more than tactical. The lawyer for the defense is anxious, of course, to keep his best case forward, but more than this is at stake. Since one case has implications so far-reaching, that case, in all fairness to Congress and the public, ought to be a typical case of the operation of the statute. Obviously, however, the extent to which the Government can choose a typical case to test the law is extremely limited. Generally speaking, it must take the cases as it finds them. Frequently what it finds is neither advantageous to the Government's position nor fair to the statute itself.

In renegotiation the Lincoln Electric case, the first on file, gave every indication of becoming the test suit. It had certain advantages for that purpose. Counsel for Lincoln were able and fair and it was certain that the issues would be fully and fairly debated. But the Lincoln case, as a test case, was in many ways defective. For one thing it did not well illustrate the nature of the government procurement problem. The products manufactured by the plaintiff were not typical war materiel. For another, it was an equity suit and the Government was much concerned with the possibility that even though the lower court took jurisdiction, the Supreme Court might reach a contrary conclusion and refuse to pass on the constitutional questions. This would have been serious indeed if the lower court voted against validity. As it turned out, thanks largely to the vagaries of fate, the Lincoln action was in no sense the test case. That honor, if such it be, fell to Judge Ben Harrison's case in the southern district of California, Spaulding v. Douglas Aircraft Company. ${ }^{2}$ Here, too, difficulties developed. After considering elaborate briefs on the constitutional issues, Judge Harrison finally concluded that the plaintiffs were estopped from attacking the statute. This, however, proved to be only a temporary setback in the campaign for a decision. The Circuit Court of Appeals for the Ninth Circuit reversed the lower court on the estoppel question and, without sending the case back, decided the constitutional issues in favor of validity. ${ }^{28}$ Manlove \& Spaulding

that problem within the common law framework of case-by-case consideration of constitutional issues. However, since American constitutional theory permits the Court to nullify the work of Congress, every effort must obviously be made to see to it that tho Court is fully informed. The technique worked out in the renegotiation cases may be a step in the right direction.

2 i (S. D. Cal. 1943) 60 Fed. Supp. 985.

28 (C. C. A. 9th 1946) 154 F. (2d) 419. 
paid the renegotiation bill and the case went no further. But the Ninth Circuit decision, the first on that level, had a substantial effect on the remaining litigation. ${ }^{28}$

Once the decisions in the lower courts began to accumulate in favor of the statute, the Government turned to other problems incidental to the renegotiation litigation. For one thing, as the war prograin came to an end and the possibilities for administrative garnishment were sharply reduced, the burden of collecting renegotiation debts fell increasingly on the courts and machinery had to be provided to service a great number of collection cases. Some of the cases as they came to hand were a great tribute to human ingenuity. The complexity of the corporate arrangements, the intricacy of the corporate transfers and the multiplicity of the fraudulent conveyances which were evolved to escape renegotiation liability were well nigh beyond belief. Government tactics in general were simple enough. Without trying to unravel what had been so laboriously confused, the Government alleged that the entire scheme was a fraud and that its perpetrators must bear responsibility for the renegotiation debt. Fraud rests heavily on the conscience and in many cases the debtors finally came forward to confess liability and pay what was owing. ${ }^{80}$

More perplexing than the fraudulent debtor was his opposite extreme, the contractor, sincerely patriotic and anxious to do his best for his country, who agreed to make profit refunds which for one reason or another turned out to be plainly beyond his ability. As long as it could honestly be said that enforcement of the renegotiation debt would impede war production, the Government had in the First War Powers Act a weapon with which to grant relief. But in most cases there was little or nothing that the renegotiation officials or the Attorney General could do to be of assistance. The power of government officers to reduce or modify obligations owing to the United States is and must be extremely limited. Congress establishes policy for the

20 It is frequently suggested that the Government in some fashion can select the judge to whom a case is assigned. If the Government in truth has a technique for making this selection it was never revealed to the lawyers working on renegotiation. They took the judicial assignments as they found them. As often as not these assignments increased rather than reduced the difficulties of the Government position.

80 The fraudulent debtor appeared in another manifestation. As might be expected a good many people who profited enormously from the war finally over-reached themselves and became largely insolvent. They then asked that the Government cancel the renegotiation debt upon payment of an amount, to be ohtained from friends and relatives, which was roughly equivalent to the present worth of the debtor. The Government agreed but insisted on an F.B.I. investigation. On more than one occasion the F.B.I. succeeded in disclosing assets sufficient to pay the renegotiation debt in full. 
nation. It neither can nor should grant an executive officer general authority to abrogate that policy in the interest of what in the particular case he may believe to be justice. The Government tried hard to relieve genuine misfortune. Sometimes by one route or another that relief could be provided; but not by any means always nor, for the personal taste of the government officials, often enough.

No appraisal of government litigation tactics in connection with renegotiation, or elsewhere for that matter, can be complete without some attention to the influence of Congress. The Government customarily debates its cases in two forums: once before the courts and once before the Senator or Representative who finds himself interested. On occasions much too numerous for their convenience, government attorneys handling renegotiation litigation were called upon to explain lengthily some particular case to a Congressman anxious to do his best for his constituent. In most instances if the Government was right the Congressman was entirely prepared to say so and that was an end of the matter. On a few occasions efforts were made to produce by political influence results which could not otherwise be justified, but never were such suggestions kindly received and never were they successful.

The real importance of Congress to the renegotiation litigation arose, of course, not from the acts of individual Congressmen but from the position of Congress itself. Although Congress gave scant attention to renegotiation when it began, it eventually gave the statute almost continuous scrutiny, ${ }^{31}$ and occasionally the problems with which it concerned itself had a direct bearing on the course of the renegotiation cases in the courts. For instance, it was suggested from time to time that the Act be amended to authorize specifically a review of Tax Court renegotiation decisions equivalent to the review

31 The Government brief in the Lichter case (p. 49) lists eight Congressional hearings on renegotiation and six reports from Congressional committees. One of the hearings, the hearing in 1943 before the House Naval Affairs Committee, had an unusual purpose. Congressmen, generally speaking, hear little or nothing from those who support a law. They hear at length from its opponents. This inevitably creates a Congressional atmosphere biased in favor of modification or repeal. The renegotiation program in 1943 was in serious danger of repeal. To restore the balance the defenders of the Act seized upon the June 1943 House Naval Affairs Committee hearing to support the statute. Men such as Earl O. Shreve, Vice-President of General Electric Corporation, J. F. Metten, Chairman of the Board, New York Shipbuilding Corporation, Roger Williams, Executive Vice-President, Newport News Shipbuilding \& Drydock Co., Donaldson Brown, Vice-Chairman, General Motors Corporation, and Roscoe Seybold, Vice-President and Counptroller, Westinghouse Electric \& Manufacturing Co., appeared before the Committee and defended renegotiation. 
provided for cases arising under the revenue laws. The advocates of this proposal seemed to feel that they could succeed in Congress only if they obtained Department of Justice approval of their proposition. The Department was unimpressed. An informal poll of private counsel practicing in the Tax Court indicated not only that the Tax Court stood very high in the judgment of the Bar but that few lawyers were prepared to say that the circuit courts on fact questions added substantially to Tax Court decisions. Thus it seemed reasonably clear that although circuit court review of renegotiation cases would undoubtedly prolong the litigation it was not likely to lead in the end to a better result. The Government opposed the proposal for amending the Act and the committees agreed. ${ }^{32}$

On other occasions it was the Government rather than private counsel who sought Congressional aid on litigation problems. It was to Congress, for example, that government counsel turned in seeking support for the Government's position on equity jurisdiction. The failure of the statute to provide specifically for a refund of amounts determined by the Tax Court to have been erroneously collected left open to private litigants an argument that Tax Court relief was so uncertain that equity should take command. The obvious remedy was to obtain legislation making specific what was plainly implied. But to obtain an amendment to the Act itself was a large undertaking with results beyond prediction. The Government compromised. It sought and eventually obtained what could hardly be denied: an appropriation for making the necessary refunds. ${ }^{33}$ This, the Government argued, demonstrated the good faith of Congress. ${ }^{34}$

In general and in spite of occasional misunderstandings the relations between the government renegotiation lawyers' cases and the Congressional committees attending to the Act were good; and, at

32 This conclusion has since been reversed. The current and newly enacted version of the Renegotiation Act contains a provision for circuit court review of Tax Court decisions.

33 Pub. L. No. 40, 79th Cong. 1st Sess.

34 This appropriation Iegislation held elements of surprise. In their eagerness to facilitate payment of any refund which the Tax Court found owing, Government counsel persuaded the Appropriation Committees to authorize refunds on the basis of a simple certificate from renegotiation officials reciting the Tax Court decision and thus to shortcut the cumbersome refund procedure usually established. Much to their astonishment and somewhat to their dismay, the Government lawyers discovered when they went to court that their effort to be helpful was thoroughly misunderstood. Private counsel vigorously contended that in obtaining the certification arrangement the renegotiation officials had a devious purpose not to facilitate but to defeat the refund procedure. The courts, fortunately, were not so skeptical. 
least on the lawyers' side, they were founded upon genuine respect and esteem. No one working on renegotiation could fail to be impressed with the capacity of Congress, when it had the time and felt the inclination, to do an excellent job. The statute as originally passed was poorly considered, hastily adopted and clumsily drafted; but once Congress began to give genuine attention to renegotiation its methods and conclusions were equally beyond reproach. To attend upon the mature Congressional consideration of renegotiation questions was an enlightening and heartening experience. 